\title{
Gross Domestic Product Per Capita and Individual Income Tax Revenue: Empirical Evidence from Vietnam
}

\author{
Nguyen Huu Cung \\ Faculty of Business Management, Hanoi University of Industry, Hanoi, Vietnam \\ Email address: \\ nguyenhuucung@haui.edu.vn

\section{To cite this article:} \\ Nguyen Huu Cung. Gross Domestic Product Per Capita and Individual Income Tax Revenue: Empirical Evidence from Vietnam. \\ International Journal of Business and Economics Research. Vol. 8, No. 6, 2019, pp. 369-374. doi: 10.11648/j.ijber.20190806.16
}

Received: September 28, 2019; Accepted: October 15, 2019; Published: October 23, 2019

\begin{abstract}
Taxes are the most important revenue source for the state budget. Income from individual income tax as a percentage of total tax revenue is increasing according to the development process of each country. The purpose of the article is to analyze the relationship between GDP per capita and individual income tax revenue in Vietnam. Empirical method is employed on secondary time series data set during the period 1999-2018. Econometric tools are employed to present and analyze the collected data from concerned bodies. The result shows that the GDP per capita has a positive effect on individual income tax revenue at $1 \%$ significant level. Moreover, the article also finds that tax revenues during the period of the individual income tax law are higher than the period of the income tax ordinance for high-income earners.
\end{abstract}

Keywords: Income Tax, Individual Income, Tax Revenue, Individual Income Tax, Vietnam

\section{Introduction}

The appearance of the state requires facilities to ensure the conditions for the state to exist and perform its functions. The state determines the constitutional power to enact necessary laws as a basis for distributing gross social products and national income into a centralized monetary fund of the state, including tax laws. The emergence of surplus products in the society is the main basis of generating tax revenue for the existence and development of the state. Thus, tax is a compulsory contribution that is regulated by the state into law so that taxpayers can pay it into the state budget to spend public purposes. This contribution is in cash directly and cannot be paid in products or services. The tax system has a main function to raise enough tax revenue to finance essential expenditures on the goods and services provided by government [14]. In fact, there are many taxes in each country's tax system. The role and revenue of each tax is different. For direct taxes, revenue from corporate income tax accounts for the highest proportion in most developing countries, while revenue from individual income tax is the highest in developed countries. Another study calculated that corporate income tax revenue during the period of 2007 2011, 13.96\% in China (ranked the 2nd after VAT), 30.73\% in Vietnam (ranked the 1st) [4]. Based on The Huffington
Post Canada the first time in Canadian history, more than half of the federal government's revenue in 2014 will come from individual income tax [3]. Moreover, according to the statistical data, average annual in the period 1999-2016, revenue from corporate income tax is more than individual income tax in Vietnam (respectively, VND 184,357 billion and VND 21,373 billion).

In fact, the state budget depends largely on revenues from taxes, so according to the development history of countries, tax laws are increasingly completed and be always amended based on the socio-economic development of each period. Law on individual income tax must not also be an exception. The application of individual income tax is effective or not depends on the purpose and approach viewpoint of each country and period. This tax was applied later than corporate income tax, but until now it is popularly applied in most countries around the world. Overall in the countries, the application of this tax is in two directions and has happened in both developed and developing countries $[1,2]$. Firstly, the burden ratios of individual income tax is consistent with the tolerance of the people, its role will promote optimal effects in both increasing budget revenues and regulating equitable income. Secondly, vice versa, this tax will not promote its role and will have a negative impact on the economy and people's living standards in the event that its burden rate 
exceeds the tolerance of the people.

In Vietnam, the law on individual income tax was officially applied on 1 January 2009 and has replaced the income tax ordinance for high-income earners. Taxable income includes main types of income such as income from salary and wages, income from business and production of goods and services, income from capital investment, copyright and franchise activities, income from transfer of capital, income from transfer of real estate, income from capital investment, income from franchises, income from inheritances and receipts of gifts, others. For income from salary and wages, Vietnam individual income tax rates are progressive to $35 \%$ and there are seven tax brackets for 2019: $5 \%, 10 \%, 15 \%, 20 \%, 25 \%, 30 \%$ and $35 \%$. Until now, revenue from this tax has increased over the years, for example, VND 1,856 billion in 1999, VND 12,940 billion in 2008 and VND 96,869 billion in 2018. What are the most important factors that determine individual income tax revenue? This is an issue that needs answers, from which to find solutions to improve the efficiency of individual income tax collection without exceeding the endurance of the people. In the scope of this article, the author focuses on analyzing the relationship between GDP per capita and individual income tax revenue in Vietnam. Moreover, the article also compares the impact of GDP per capita on individual income tax revenue among Law and Ordinance application period.

\section{Literature Reviews}

Individual income tax is one of the most important taxes in developed countries as well as developing countries, but determining its optimal burden to achieve revenues from this tax is a difficult task for any country. To collect right and sufficiently, governments must identify the factors affecting individual income tax revenue. In fact, there are many factors such as GDP at current prices, GDP per capita, inflation, corruption, tax collection management, tax rate, trade openness, investment openness, economic freedom, others. The relationship between per capita income and individual income tax revenue can have two directions of positive or negative effects. Firstly, the impact of GDP at current prices, GDP per capita, tax collection management, tax rate, trade openness, investment openness, economic freedom on individual income tax revenue is a positive effect. Secondly, inflation and corruption have a negative effect on individual income tax revenue.

The results of a study indicate policy implications for increasing tax revenues [7]. This study finds that an increase in real per capita income and trade openness boost tax revenues, meanwhile the relationship between corruption, inflation, political instability, and tax revenues is a negative effect. The result of another study finds that in a number of developing countries, fiscal corruption has a negative effect on tax revenue and is a key factor behind the poor revenue performance [5]. Other research also finds that the relationship between corruption and tax revenue is a negative sign and significant [6]. This means that a decrease in corruption will be expected to enhance tax revenue. Inflation has a negative effect and significant on tax revenue, but the impact of GDP per capita income, foreign aid and industrial value added share of GDP on tax revenue is a positive sign and significant [8]. Another study shows that the significant determinants of tax revenue in Albania are inflation, unemployment and GDP [9]. With forty two years data in Nigeria, the research result shows that the main determinants of tax revenue are the level of change in income, rate of inflation and exchange rate [10]. Another research used time series data set for the years $1999 / 00$ to $2015 / 16$ and the results find that in constant condition of other factors, a $1 \%$ increase in real GDP per capita income results in approximately raise in tax revenue percentage of GDP by 0.20 percent [11]. This means that GDP per capita income has a positive and significant effect on tax revenue.

In Vietnam, there are also several studies on individual income tax. A research analyzes on the differences of individual income tax regime between Vietnam and China and the result shows that several contents of China's individual income tax law are more progressive than Vietnam [1]. Moreover, this study also suggests that China's application is more effective than Vietnam. In another research, the authors conducted two-sided testing on the relationship GDP per capita and individual income tax revenue per capita during the period $2002-2011$ and the result finds that a VND 1 billion increase in Vietnam's GDP per capita results in individual income tax revenue per capita from VND 0.0126787 billion to VND 0.0312373 billion. This means that the impact of GDP per capita on individual income tax revenue per capita is a positive significant. A secondary time series data set for the years from 2002 to 2011 was used in a study on determinants of individual income tax revenue in Vietnam, the result finds that an increase in GDP per capita is the most important factor effecting individual income tax revenue [2, 12]. The empirical study on determinants of individual income tax revenue in Vietnam concluded that there are three factors effecting individual income tax revenue during 2002-2016, such as GDP at current prices, tax burden and inflation [13]. The impact of GDP at current prices and tax burden on individual income tax revenue is a positive significant while inflation has a negative effect on individual income tax revenue. Thus, in the scope of the author has yet no found any research on the effect of GDP per capita on individual income tax revenue in Vietnam with the updated time period. This is the research gap and is also a major task of this article.

\section{Data and Model}

The author uses an empirical analysis method to determine the impact of GDP per capita on individual income tax revenue. Time series data in during the period 1999-2018 of individual income tax revenue and GDP per capita was obtained from Ministry of Finance and General Statistics Office in Vietnam. 
A correlation and regression analysis is conducted 2 steps. Step 1, the author analyzes the relationship between a dependent variable (GDP per capita) and an independent variable (individual income tax revenue). The regression results of this step has statistical significance through indicators such as $\rho_{\text {_value }}=0.000<\alpha=0.05$, block coefficient $\hat{\beta}_{1}$ and $\hat{\beta}_{2}$ be consistent with the economic theory, a large $\mathrm{R}^{2}$ value. However, due to Durbin-Watson test be too small, this model has an autocorrelation phenomena. To remedy this violation, the author will use the general differential equation to implement the regression process. The regression results are statistical significance. Step 2, the author compares the effect of GDP per capita on individual income tax revenue among the Law and Ordinance period. The regression results prove that the model is consistent with the economic theory.
The OLS method is applied to perform analysis on the simple linear regression between GDP per capita and individual income tax revenue in Vietnam. Specifically, GDP per capita is an independent variable (PCI - VND) and individual income tax revenue is a dependent variable (TAX - billion VND). The regression equation has the following format:

$$
\operatorname{TAX}_{t}=\hat{\beta}_{1}+\hat{\beta}_{2} \mathrm{PCI}_{t}+\mu_{t}
$$

The value of Durbin-Watson test shows that the equation (1) has an auto-correlation phenomena grade 1. The author uses the general differential equation to remedy this violation. Therefore, we need to test autocorrelation phenomena based on the consideration of the remainder $e_{t}$ depends on its latency or not.

$$
T A X_{t}+\hat{\rho} \operatorname{TAX}_{t-1}=\hat{\beta}_{1}(1-\hat{\rho})+\hat{\beta}_{2}\left(\mathrm{PCI}_{t}-\hat{\rho} P C I_{t-1}\right)+\left(\mu_{t}-\hat{\rho} \mu_{t-1}\right)
$$

The autocorrelation test with the extra regression:

Model has not block coefficient:

$$
\varepsilon_{t}=\alpha_{1} \varepsilon_{t-1}+v_{t}
$$

Model has block coefficient:

$$
\begin{aligned}
& \varepsilon_{t}= \alpha_{0}+\alpha_{1} \varepsilon_{t-1}+v_{t} \quad \text { (4) grade } 1 \text { by } \hat{\rho} \cong 0.56 \text {, to subs } \\
& T A X_{t}+0.56 \mathrm{TAX}_{t-1}=\hat{\beta}_{1}(1-0.56)+\hat{\beta}_{2}\left(\mathrm{PCI}_{t}-0.56 \mathrm{PCI}_{t-1}\right)+\left(\mu_{t}-0.56 \mu_{t-1}\right)
\end{aligned}
$$

The results of Equation (3): E $(-1)=0.564580$, DurbinWatson stat $=1.513699$

The results of Equation (4): E (-1) $=0.572179$, DurbinWatson stat $=1.526640$

Through the DW statistics and the extra regression of Equation (3) and (4), the correlation coefficient estimation grade 1 by $\hat{\rho} \cong 0.56$, to substitute into Equation (2):

\section{Results and Discussion}

\subsection{Correlation Analysis Between TAX and GDP Per Capita}

After performing the operations, the regression results are in the data table below:

Table 1. Regression Results of Equation (1).

\begin{tabular}{lllc}
\hline Variable & Coefficient & Std. Error & t-Statistic \\
\hline C & -9469.530 & 2347.788 & -4.033383 \\
PCI & 0.001570 & $7.83 E-05$ & 20.04647 \\
R-squared & 0.957129 & Durbin-Watson stat & 0.0008 \\
Adjusted R-squared & 0.954747 & Prob (F-statistic) & 0.0000 \\
\hline
\end{tabular}

Source: Correlation Output of Data Collected.

In Table 1, due to $p_{-}$value of GDP per capita is so small, so the impact of GDP per capita on the corporate income tax burden is too strong. The table of the regression results also show, $\mathrm{R}^{2}=0.957129$, means that the change of the independent variables explained $95.7129 \%$ of the dependent variable's fluctuation. $\mathrm{R}^{2}$ and F-statistic are large, the regression model is appropriate. However, the value of Durbin-Watson test is $\mathrm{d}=0.894566$ while the sample numbers $\mathrm{n}=20$, number of independent variable in the model $\mathrm{k}^{\prime}=1$, inferred $d_{L}=1.201$ and $d_{U}=1.411$, due to $\mathrm{d}<$ $\mathrm{d}_{\mathrm{L}}$, concludes that the model is autocorrelation phenomena grade 1 .

Table 2. Regression Results of Equation (3).

\begin{tabular}{llll}
\hline Variable & Coefficient & Std. Error & t-Statistic \\
\hline E (-1) & 0.564580 & 0.243653 & Prob. \\
R-squared & 0.229195 & Durbin-Watson stat & 0.0325 \\
Adjusted R-squared & 0.229195 & & 1.513699 \\
\hline
\end{tabular}

Source: Correlation Output of Data Collected. 
Table 3. Regression Results of Equation (4).

\begin{tabular}{|c|c|c|c|c|}
\hline Variable & Coefficient & Std. Error & t-Statistic & Prob. \\
\hline $\mathrm{C}$ & 269.3312 & 1312.135 & 0.205262 & 0.8398 \\
\hline E (-1) & 0.572179 & 0.253129 & 2.260423 & 0.0372 \\
\hline R-squared & 0.231100 & \multicolumn{2}{|c|}{ Durbin-Watson stat } & 1.526640 \\
\hline Adjusted R-squared & 0.185871 & \multicolumn{2}{|c|}{ Prob (F-statistic) } & 0.037206 \\
\hline
\end{tabular}

Source: Correlation Output of Data Collected.

Table 4. Regression Results of Equation (5).

\begin{tabular}{lllc}
\hline Variable & Coefficient & Std. Error & t-Statistic \\
\hline C & -4365.225 & 2232.830 & -1.955019 \\
PCI-0.56*PCI (-1) & 0.001607 & 0.000145 & 0.0672 \\
R-squared & 0.878388 & Durbin-Watson stat & 11.08101 \\
Adjusted R-squared & 0.871234 & Prob (F-statistic) & 1.0000 \\
\hline
\end{tabular}

Source: Correlation Output of Data Collected.

Based on the regression results in Table 4 , sign of $\hat{\beta}_{1}, \hat{\beta}_{2}$ are in accordance with economic theory. $\hat{\beta}_{1}$ has a negative sign, means that the economy stopped working (GDP $=0$, GDP per capita $=0$ ), revenue from taxes (including revenue from individual income tax) is zero. The value $d$ of DurbinWatson test is $\mathrm{d}=1.567439>\mathrm{d}_{\mathrm{U}}=1.411$, meanwhile the significance level $\alpha=5 \%=0.05$, the sample numbers $n=20$, number of independent variable in the model $\mathrm{k}^{\prime}=1$, inferred $d_{L}=1.201$ and $d_{U}=1.411$. Due to $d>d_{U}$, so the results show that the model is not an autocorrelation phenomena. At the same time, due to $p_{-}$value of GDP per capita is so small, so the effect of GDP per capita on the individual income tax revenue is too strong. The table of the regression results also find that $\mathrm{R}^{2}=0.878388$, which means the change of GDP per capita explained $87.8388 \%$ of the dependent variable's fluctuation. $\mathrm{R}^{2}$ and F-statistic are so large, the regression model is appropriate. After the change of variable, the block coefficient estimate of the differential model is -4365.225 , therefore the block coefficient estimate of the model (1): $\hat{\beta}_{1}$ $=[-4365.225 /(1-0.56)]=-9920.966$ and the slope estimate of the original model $\hat{\beta}_{2}=0.001607 . \hat{\beta}_{2}$ shows that, in constant of other factors, GDP per capita increases to 1 VND, individual income tax revenue increases to VND 0.001607 billion. Thus, GDP per capita has a positive effect and significant on individual income tax revenue in Vietnam during the period 1999-2018. This result is also consistent with economic theory and a number of previous studies such as $[2,7,8,11,12]$.

\subsection{Addition of Independent Variable into Original Model}

The author will draw the graph of GDP per capita by individual income tax revenue.

The graph of the first period from 1999 to 2009 (11 left points) is less steep than the later period from 2010 to 2018 (9 right points). This also is the two periods of Ordinance on individual income tax and Law on individual income tax.
Thus, due to the period factor is a qualitative variable, the author will add a dummy variable in the regression model.

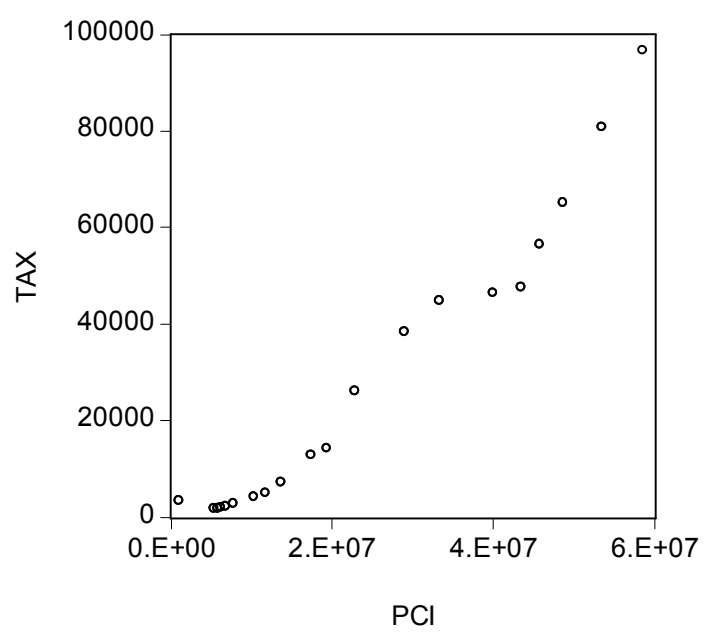

Figure 1. Determination of qualitative variable.

Set $\mathrm{D}$ is dummy variable: $\mathrm{D}=0$ with the observation 1999 $-2009$.

$\mathrm{D}=1$ with the observation 2010 - 2018 .

The regression model has the following form.

$$
\mathrm{TAX}=\hat{\beta_{1}}+\hat{\beta_{2}} \mathrm{PCI}+\hat{\beta}_{3} \mathrm{D}+\hat{\beta}_{4} \mathrm{D} * \mathrm{PCI}+\mu_{t}
$$

The first period:

$$
\mathrm{TAX}=\hat{\beta}_{1}+\hat{\beta}_{2} \mathrm{PCI}+\mu_{t}
$$

The later period:

$$
\mathrm{TAX}=\left(\hat{\beta}_{1}+\hat{\beta}_{3}\right)+\left(\hat{\beta}_{2}+\hat{\beta}_{4}\right) \mathrm{PCI}+\mu_{t}
$$

The regression results are in the data table below: 
Table 5. Regression Results of Equation (6).

\begin{tabular}{lllll}
\hline Variable & Coefficient & Std. Error & t-Statistic & Prob. \\
\hline C & -1505.627 & 3266.440 & -0.460938 & 0.6510 \\
PCI & 0.000720 & 0.000301 & 2.397565 & 0.0291 \\
D1 & -16564.81 & 7636.611 & -2.169131 & 0.0455 \\
D1*PCI & 0.001059 & 0.000341 & 3.110169 & 0.0067 \\
R-squared & 0.973324 & F-statistic & & 194.5966 \\
Adjusted R-squared & 0.968322 & Prob (F-statistic) & & 0.000000 \\
\hline
\end{tabular}

Source: Correlation Output of Data Collected.

The regression equation (6) has the form:

$$
\begin{aligned}
& T A X=-1505.627+0.000720 \text { PCI } \\
& -16564.81 \mathrm{D}+0.001059 \mathrm{D} * \mathrm{PCI}
\end{aligned}
$$

The regression equation (7) has the form:

$$
T \mathrm{AX}=-1505.627+0.000720 \mathrm{PCI}
$$

The regression equation (8) has the form:

$$
T \mathrm{AX}=-18070.437+0.001779 \mathrm{PCI}
$$

The regression results show, the relationship between GDP per capita and individual income tax revenue has a positive effect and significant at 5\% level of significance. This means that GDP per capita increases to $1 \mathrm{VND}$, an increase in individual income tax revenue is VND 0.000720 billion during the period 1999-2009. Similarly, at 5\% level of significance, individual income tax revenue increases to VND 1 billion by an increase to 0.001779 in GDP per capita during the period 2010-2018. From two above conclusions, we could assert that GDP per capita increases to $1 \mathrm{VND}$, individual income tax revenue in the period 1999-2009 is lower than the period 20010-2018. The reasons that, average annual, GDP at current prices in the period 2010-2018 is higher than the period 19992009 (about 4.34 times more), many people have higher incomes. Moreover, the income tax ordinance on high-income earners was replaced by the individual income tax law, the contents of the law were completed more, an expansion in taxable subjects, many types of income were included in the law that were not previously included in the ordinance. Organizational structure system in tax collection and tax administration of tax authorities was completed more and professional. Finally, the provisions of the law are stricter and binding higher than the ordinance, therefore people's awareness of paying taxes during the law period was improved more than the ordinance period.

This study builds a simple model with an independent variable (GDP per capita), and a model on the impact of GDP per capita on individual income tax revenue in comparing the relationship between the period of Law and Ordinance. The results of these two models are consistent with economic theory and previous studies $[2,7,8,11,12]$. The similarity between this research and previous studies is that the relationship between GDP per capita and individual income tax revenue has a positive effect and significant. Although GDP per capita is a main and most important reason in rising individual income tax revenue, but there are still a number of other factors that could also affect individual income tax revenue such as perfection and enforcement of tax law, organizational structure of tax collection and administration, tax corruption, others. Therefore, this is the research gap for the next studies of the author.

\section{Conclusion and Policy Implication}

In this article, the author performs a regression and correlation analysis on the relationship between GDP per capita and individual income tax revenue. The result shows that the effect of GDP per capita on individual income tax revenue is a positive significant at 5\% level of significance. How to increase individual income tax revenue through GDP per capita in the coming period in Vietnam? Firstly, Vietnam maintains a high growth rate and continues to be among the countries with the highest growth rates in the world. Secondly, Vietnam uses flexible monetary and fiscal policies to stimulate economic growth. Because, after years of economic crisis, Vietnam has always controlled monetary policy and tightened public expenditure, many people and small and medium enterprises were difficult to access bank credit and other capital mobilization channels, so annual economic growth rate of Vietnam in recent years (2009-2018) was about $6.3 \%$ while during the period 1999-2008 was about $7.21 \%$. Thirdly, continue to expand international economic relations to attract foreign investment to supplement social investment capital, thereby contributing to economic growth. Finally, in fact, a comparison result shows that due to individual income tax revenue in applying the law was much higher than the ordinance. Socio-economic situation has many changes over time, many types of newly formed incomes, change of many macroeconomic indicators, therefore law on individual income tax continues to be revised and supplemented several articles to increase tax revenue without exceeding the tolerance of the people.

\section{References}

[1] Liu et al. (2012). Analysis of Differences of The Personal Income Tax Regime between Vietnam and China. 2nd International Conference on Financial Management and Economics (Singapore), Vol. 43, pp. 231-237.

[2] Nguyen Huu Cung et al. (2013). Determinants of Revenue of Personal Income Tax in Vietnam. In Proc. of The 4th Int. Asia Conf. on Industrial Engineering and Management Innovation (IEMI'2013), Taiwan, 2013, pp. 126-130, ISBN: 978-3-64240059-9. 
[3] Daniel Tencer (2013). Canada's Tax Burden Shifting Corporations onto People: Economists. The Huffington Post Canada. https://www.huffingtonpost.ca/2013/11/24/corporatepersonal-taxes-canada_n_4333694.html.

[4] Nguyen Huu Cung (2015). Corporate Income Tax Burden and Its Determinants: Evidence from Vietnam. Advances in Management and Applied Economics, Vol. 5, No. 3, pp. 103120.

[5] Chand and Moene (1997). Controlling Fiscal Corruption. IMF Working Paper, No. 97 (Washington DC: International Monetary Fund).

[6] Gupta, S. (2007). Determinants of Tax Revenue Efforts in Developing Countries. IMF Working Paper 07/184. Washington: International Monetary Fund.

[7] Amin et al. (2014). Factors affecting tax revenue in Pakistan. Journal of Finance and Economics, 2014, Vol. 2, No. 5, 149155 .

[8] Mossie (2016). Determinants of Tax Revenue in Ethiopia (Johansen Co-Integration Approach). International Journal of Business, Economics and Management, 3 (6): 69-84. DOI: 10.18488/journal.62/2016.3.6/62.6.69.84.
[9] Velaj, E. \& Prendi, L. (2014). Tax Revenue - The Determinant Factors - the Case of Albania. European Scientific Journal September, SPECIAL edition, Vol. 1, ISSN: 1857-7881 (Print), E - ISSN 1857-7431.

[10] Muibi and Sinbo (2013). Macroeconomic Determinants of Tax Revenue in Nigeria (1970-2011). World Applied Sciences Journal 28 (1): 27-35, 2013 ISSN 1818-4952. IDOSI Publications, 2013 DOI: 10.5829/idosi.wasj.2013.28.01.1189.

[11] Gobachew et al. (2018). Determinants of Tax Revenue in Ethiopia. Economics, Vol. 6, No. 1, 2018, pp. 58-64. DOI: 10.11648/j.eco.20170606.11.

[12] Nguyen Huu Cung and Liu Hua (2014). A Comparative Study on Individual Income Tax Burden of Vietnam and China. Business and Management Research, Vol. 3, No. 2, pp. 60-66. DOI: $10.5430 / \mathrm{bmr} . v 3 \mathrm{n} 2 \mathrm{p} 60$.

[13] Than Thanh Son and Nguyen Huu Cung (2019). Individual Income Tax Revenue and Its Determinants: A Case Study in Vietnam. Advances in Economics and Business, Vol. 7, No. 5, pp. 185-193, DOI: 10.13189/aeb.2019.070502.

[14] Pius, K., \& Raymond, E. (2014). Factors affecting tax revenue in Pakistan. International Journal of Advanced Research, volume 2 , issue 2, 449-458. 